Agricultural Journal 6(2): 40-46, 2011

ISSN: $1816-9155$

(C) Medwell Journals, 2011

\title{
Measuring Technical Efficiency of Yam Farmers in Nigeria: A Stochastic Parametric Approach
}

\author{
Oluwatusin Femi Michael \\ Department of Agricultural Economics and Extension Services, \\ University of Ado-Ekiti, Ado Ekiti, Nigeria
}

\begin{abstract}
The study measured the level of technical efficiency in Nigerian yam farming using yam producers survey data. The primary data for the study were collected randomly from 240 yam farmers selected with multistage sampling technique across 12 communities in Osun state, Nigeria. Data collected were analyzed using descriptive statistics, Chi-square statistics and Stochastic Frontier Production Function model (SFPF). The empirical results revealed that the cost of yam sett used, labour used and farm size were significantly different from zero and of importance in production of yam. Also, the year of formal education, farming experience and access to credit were the main socio-economics characteristics affecting the technical inefficiency of yam farmers. In addition, the technical efficiencies of the yam farms ranged between 0.343 and 0.962 with a mean of 0.698 . This shows that on the average, farmers were able to obtain about $70 \%$ of potential output from a given mix of inputs. The return to scale of 1.119 obtained shows that yam farms were operating in stage 1 of the production surface (increasing returns to scale). The study therefore, recommends that research institutes should make available an improved variety of yam sett. Also year of formal education, farming experience and access to credit should be manipulated by policy makers in order to improve the yam farmers technical performance.
\end{abstract}

$\underline{\text { Key words: Stochastic frontier, technical efficiency, inefficiency, production, yan farming, formal education }}$

\section{INTRODUCTION}

The importance of agriculture in the economy of Nigeria cannot be overemphasized. The value of non-oil exports stood at 38.2 billion and $66.6 \%$ of this was accounted for by agricultural produce. In Nigeria, in order to increase food self-sufficiency and agricultural production, efficiency allocation of the meagre resources at the farmers disposal should be encouraged. Soludo opined that $60 \%$ of arable land in Nigeria are left fallow.

According to Akinwunmi (1999), most arable farmers in Nigeria are poorly endowed in terms of farm inputs. The inefficient allocation of these resources by the farmers has made Nigerian agriculture to remain at the traditional and rudimentary level. This trend must be reversed in order to allow Nigeria be one of the top economies in the year 2020; achieve its potentials and meet the millennium goals. Furthermore, in Nigeria, due to rise in population, the demand for agricultural products is continually rising. This has resulted in the need to allocate farm resources efficiently.

Moreover, yams, annual or perennial tuber-bearing and climbing plants are native to warmer regions of both hemispheres. The genus Dioscorea has over 600 species but only a few are cultivated for food and medicine. The major edible species of African are white Guinea yam (D. rotundata Poir.), yellow Guinea yam (D. cayenensis Lam.) and trifoliate or bitter yam (D. dumetorum Kunth.). Water or greater yam (D. alata L.) and lesser yam (D. esculenta [Lour.] Burkill) are edible species that originated from Asia. Also cush-cush yam (D. trifida L.) is native to America. By virtue of its excellent palatability, yam is a high value crop cultivated throughout the tropics. It is a primary commodity in West Africa and New Guinea. In terms of cultivation and utilization, White Guinea yam and water yam are the most important food yams. It has been observed that in Africa, consumer demand for yam is generally very high and despite its high cost of production, yam cultivation is very profitable.

Yam tubers may be eaten with sauce direct after roasting, boiling or frying in oil. The tubers may also be pounded into a thick paste after boiling and is eaten with soup. It may be processed into flour or cooked into pottage with added protein sauce and oils. In addition, cultural values are attached to yam, in Nigeria. During weddings and other social and religious ceremonies, the size of yam tubers presented reflects one's social status. Even yam festival is celebrated annually by some communities in West Africa. Over the years, the price of yam has remained generally high, since low production 
has kept them scarce. According to International Institute of Tropical Africa, yams are produced on 5 million hectares in about 47 countries in tropical and subtropical regions of the world.

In 2005, based on FAO statistics, 48.7 million ton of yam were produced worldwide. About $97 \%$ of these came from sub-Sahara Africa. In 2005, Nigeria has been regarded as the leading producer of yam with 34 million ton followed by Cote d'Ivore ( 5 million ton), Ghana ( 3.9 million ton) and Benin (2.1 million ton). But annually, Ghana exports the largest quantity of yams (about 12,000 ton). Benin has the highest average yam consumption per capita per day $(364 \mathrm{kcal})$ followed by Cote d'Ivore (342 kcal), Ghana $(296 \mathrm{kcal})$ and Nigeria (258 kcal).

Study carried out in Kogi State, Nigeria found that roughly $70 \%$ of yam production costs were for planting materials. As the campaign for household food security gains momentum all over the world and since extreme poverty and hunger must be eradicated by year 2015 , yams are some of the food crops whose production has got to be emphasised. Yam being an important food crop for at least 60 million people in West Africa (Babaleye, 2005 ), it is necessary to lower its production cost and scale up its production through an efficient use of its production resources.

Also with the movement of African to Europe and the new worlds, the demand for yam is increasing everyday on the export markets as people in the Diaspora continue to show interest in African foodstuffs such as yam.

In addition in order to help producers, processors and other entrepreneurs to better participate in the yam sub-sector, there is need to study the technical efficiency among its producers. Moreover, apart from allocative efficiency, overall economic efficiency is also driven by changes in technical efficiency. The focus of this study is on measuring the level of technical efficiency in Nigerian yam farming using yam producers survey data and identifying the variables affecting their technical performance.

\section{MATERIALS AND METHODS}

Study area: The study was conducted in Osun state of Nigeria. Its capital is Osogbo. It is bounded in the North by Kwara state in the East partly by Ekiti state and partly by Ondo state in the South by Ogun state and in the West by Oyo state. This state came into existence on 27 th August, 1991. The state runs an agrarian economy with a vast majority of the populace taking to farming. There are varieties of agricultural produce in the state. Food crops grown in the area include yam, cassava, cocoyam, maize, rice, cowpea, groundnut, etc. Fruits and vegetables grown include oranges, plantain, banana, mango, bread fruit, tomatoes, etc. Also livestock such as rabbit, poultry, cattle, sheep, goat, pig and sheep are reared in the state.

Sources and method of data collection: In order to achieve the stated objectives, a 3 stage sampling technique was employed in selecting the samples needed for the study. The field survey and farmers interview were carried out with the aid of questionnaire consisting of some open end questions. The respondents were farmers who cultivated yams regardless of whether or not other crops were produced. The 1st stage of selection involved the random selection of 3 local government areas. In the 2 nd stage of selection, 4 communities were randomly selected from each local government area to give a total of 12 communities in all. From the list of yam growers in the selected communities, 12 farmers were randomly selected from each community making a total of 240 yam producers. Equal numbers of yam producers was selected from each community in order to ensure equal representation and reduce biasness.

The questionnaire sought information on the socioeconomic characteristics of the respondents such as gender, age, level of income, year of formal education, farming experience, secondary occupation, marital status, etc. Moreover, information was also collected on the total value of agricultural outputs since the farmers practiced mixed cropping. The total value of yam output recorded in naira was obtained by adding cash receipts from yam sold together with those consumed in the households. Land was measured in hectares and labour in mandays for both family and hired labour. Rate of daily labour in each community was used to value family labour employed in production. Also information was elicited on the extension contacts, factor inputs such as herbicides, fertilizer, pesticides, etc.

Secondary data were collected from the state Agricultural Development Projects reports, Central Bank of Nigeria annual reports, Ministry of Agriculture, conference proceedings on yam production and International Institute for Tropical Agriculture annual reports.

Methods of data analysis: Stochastics Frontier Production Function (SFPF) was used to analyse technical efficiencies of the farms. Production efficiency is concerned with the relative performance of the method applied in the conversion of inputs into output. Efficiency measurement started with Farrel who distinguished 
between technical, allocative/price and economic efficiencies. Technical efficiency shows the ability of a firm to obtain maximum output from the given inputs. It is the ratio of output to input and the greater the ratio, the more the magnitude of technical efficiency. Allocative efficiency shows the ability of a firm to utilize the inputs in its disposal at optimal proportion given their respective prices. A firm is efficient allocatively when its production takes place at a point where the marginal value product is equal to the marginal factor cost. Economic efficiency occurs where there are both technical and allocative efficiencies.

Over the years, there has been a substantial change in the method used in estimating production functions because Farrel's measure of efficiency depends on the existence of the efficient production function with which observed performance of the firm can be compared. One of such changes is the development of stochastic frontier production model by Aigner and Meeusen and Van den Broeck. These scholars view production function as a locus of maximum output levels from a given input set and thus the output of each firm is bounded above a frontier. This frontier is believed to be stochastic in order to capture exogenous shocks beyond the control of firms. Since, all firms are not able to produce the frontier output, an additional error (second error term) is introduced to represent technical inefficiency, something which is in the control of firms.

Stochastic frontier production model is a special form of regression model which considered output variability based on 2nd part error term. The 1st error term (measurement error) takes into consideration the statistical noise or data noise while the 2 nd error term is associated with technical inefficiency as against the Ordinary Least Square (OLS) which assumes variability in output by 1st part error term (measurement error). The stochastic frontier model of parametric approach measures firm level of technical efficiency using corrected form of OLS known as Maximum Likelihood Estimate (MLE).

The original specification involved a production function which had an error term which had 2 components one to account for random effects and another to account for technical inefficiency. This model can be expressed in the following form as stated by Coelli:

$$
\mathrm{Y}_{\mathrm{i}}=\mathrm{X}_{\mathrm{i}} \beta+\left(\mathrm{V}_{\mathrm{i}}-\mathrm{U}_{\mathrm{i}}\right)(\mathrm{i}=1, \ldots, \mathrm{N})
$$

Where:

$Y_{i}=$ The production of the i-th firm

$\mathrm{X}_{\mathrm{i}}=\mathrm{Ak} \times 1$ vector of input quantities of the $\mathrm{i}$-th firm

$\beta=$ Vector of unknown parameters
$\mathrm{V}_{\mathrm{i}} \mathrm{s}=$ Are random variables which are assumed to be identically independently and normally distributed with mean zero and constant variance (iid. $\left.\mathrm{N}\left(0, \delta^{2} \mathrm{v}\right)\right)$ and represents those shocks that are not directly controlled by the farmers and independent of the $\mathrm{U}_{\mathrm{i}} \mathrm{s}$

$\mathrm{U}_{\mathrm{i}} \mathrm{s}=$ Non-negative random variables which are assumed to account for technical inefficiency in production and are often assumed to be iid. $\left|\mathbb{N}\left(0, \delta^{2} u\right)\right|$

Model specification: For the purpose of this study the stochastic production frontier for yam farmers is assumed to be of the Cobb-Douglas form following Battese and Coelli (1995). The explicit form of the model is specified as follow:

$$
\begin{gathered}
\ln Y_{\mathrm{i}}=\beta_{0}+\beta_{1} \ln \mathrm{X}_{1 \mathrm{i}}+\beta_{2} \ln \mathrm{X}_{2 \mathrm{2}}+\beta_{3} \ln \mathrm{X}_{3 \mathrm{i}}+\beta_{4} \ln \mathrm{X}_{4 \mathrm{i}}+ \\
\beta_{5} \ln \mathrm{X}_{5_{\mathrm{i}}}+\beta_{6} \ln \mathrm{X}_{6 \mathrm{i}}+\mathrm{V}_{\mathrm{i}}-\mathrm{U}_{\mathrm{i}}
\end{gathered}
$$

Where, $\ln$ represents the natural logarithm:

$Y_{i}=$ Value of yam output of $i$-th farmer (

$\mathrm{X}_{1}=$ Yam sett used (N)

$\mathrm{X}_{2}=$ Labour used (mandays)

$\mathrm{X}_{3}=$ Herbicides and pesticide used (N)

$\mathrm{X}_{4}=$ Farm size (hectare)

$\mathrm{X}_{5}=$ Fertilizer used (N)

$\mathrm{X}_{6}=$ Farm tools used (

$\beta_{\mathrm{s}}=$ Unknown scalar parameters to be estimated

Also, inefficiency model $\left(\mathrm{U}_{\mathrm{i}}\right)$ is shown as:

$$
\mathrm{U}_{\mathrm{i}}=\boldsymbol{\delta}_{0}+\boldsymbol{\delta}_{1} Z_{1 \mathrm{i}}+\boldsymbol{\delta}_{2} \mathrm{Z}_{2 \mathrm{i}}+\boldsymbol{\delta}_{3} \mathrm{Z}_{3 \mathrm{i}}+\boldsymbol{\delta}_{4} \mathrm{Z}_{4 \mathrm{i}}+\boldsymbol{\delta}_{5} \mathrm{Z}_{5 \mathrm{i}}+\boldsymbol{\delta}_{6} \mathrm{Z}_{6 \mathrm{i}}
$$

Where:

$\delta \mathrm{s}=$ Unknown scalar parameters to be estimated

$Z_{1}-Z_{6}=$ The household size (number), year of formal education (year), farming experience (year), farmers age (year), distance between farmer's house and the farm $(\mathrm{Km})$ and access to credit (yes $=1$, no $=0$ ) of the $i$-th farmer, respectively

These socio-economic variables are included in the model to show their possible effects on the technical efficiencies of the yam farmers. Since, the endogenous variable of inefficiency model designates the mode of inefficiency, a positive sign of an estimated parameter implies that the associated variable has negative effect on efficiency but positive effect on inefficiency and vice versa. According to Battese and Coelli (1995) and considering the stochastic frontier production function defined by Eq. 2, the technical efficiency of the i-th farmer 
$\left(\mathrm{TE}_{\mathrm{i}}\right)$ is defined in terms of the ratio of the observed output $\left(\mathrm{Y}_{\mathrm{i}}\right)$ to the corresponding frontier output $\left(\mathrm{Y}_{\mathrm{i}}^{*}\right)$ given the available technology. That is:

$$
\mathrm{TE}_{\mathrm{i}}=\frac{\mathrm{Y}_{\mathrm{i}}}{\mathrm{Y}_{\mathrm{i}}^{*}}=\frac{\mathrm{E}\left(\frac{\mathrm{Y}_{\mathrm{i}}}{\mathrm{U}_{\mathrm{i}}, \mathrm{X}_{\mathrm{i}}}\right)}{\mathrm{E}\left(\frac{\mathrm{Y}_{\mathrm{i}}^{*}}{\mathrm{u}_{\mathrm{i}}=0, \mathrm{X}_{\mathrm{i}}}\right)}=\operatorname{EXP}\left(-\mathrm{U}_{\mathrm{i}}\right)
$$

TE takes value on the interval 0 and 1 where 1 indicates a fully efficient farm and 0 a fully inefficient farm, that is, $0 \leq \mathrm{TE} \leq 1$. This shows that $\mathrm{TE}_{\mathrm{i}}$ indicator is interpreted as a measure of managerial efficiency, that is an expression of the farmer's ability to achieve results comparable to those shown on the production frontier. The computer programme Frontier 4.1 developed by Coelli was used to estimate the parameters of the stochastic frontier production function and the inefficiency model. Total 2 models were estimated in the course of this study. The 1st model which is the traditional response function of Ordinary Least Square (OLS) assumes that the inefficiency effects are absent.

It is a special form of the Stochastic Frontier Production Function (SFPF) model where the total output variation due to technical inefficiency is zero that is $\gamma=0$ (Jondrow et al., 1982).

The 2nd model is the general frontier model where there is no restriction here $\gamma \neq 0$. Using the generalised likelihood ratio test, the 2 models were compared for the presence of technical inefficiency effects. This is defined by the test statistic, Chi-square, $\chi^{2}$ (Greene, 1980):

$$
\begin{gathered}
\chi^{2}=-2\left\{\ln \left[\mathrm{L}\left(\mathrm{H}_{0}\right) \mathrm{L}\left(\mathrm{H}_{1}\right)\right]\right\}= \\
-2\left\{\ln \left[\mathrm{L}\left(\mathrm{H}_{0}\right)\right]-\ln \left[\mathrm{L}\left(\mathrm{H}_{1}\right)\right\}\right.
\end{gathered}
$$

Where, $\chi^{2}$ has a mixed Chi-squared distribution with the degree of freedom equal to the number of parameters imposed under the null hypothesis. $\mathrm{H}_{0}$ is the null hypothesis that $\gamma=0($ model 1$)$.

This is given as the value of the likelihood function for the frontier model while $\mathrm{H}_{1}$ is the alternative hypothesis that $\gamma \neq 0$ (model 2) for the general frontier model. When the estimated $\chi^{2}$ is lower than the corresponding critical value of $\chi^{2}$ for a stated level of significance, we accept the null-hypothesis and vice versa. The sum of output Elasticities (El) with respect to each resource was computed in order to determine the return to scale.

For the linearized Cobb-Douglas production function the coefficients of the independent variables are the direct partial Elasticities (El). When the sum of partial elasticities is equal to one $(\Sigma \mathrm{El}=1)$ it implies constant return to scale while less than and greater than 1 indicate decreasing and increasing return to scale, respectively.

\section{RESULTS AND DISCUSSION}

The summary statistics for variables in the stochastic frontier model for yam producers in Osun state, Nigeria is shown in Table 1. The average revenue from the harvested yam per farm per annum was $97,004.72$ with standard deviation of 119,561.12.

The large variability in the revenue implies, there was a wide variation in the value of yam harvested in the study area. The mean value of yam setts over the sampled farm was $29,101.42$ with a standard deviation of 35 , 868.34. The average mandays used in the production of yam was 224.30 mandays.

These findings indicated that yam farmers in the study area performed most of their farming activities with human labour. In addition, the average cost of herbicides and pesticide, fertilizer, farm tools used were 17, 403.66, 10, 994.44 and 2, 461.71, respectively.

The farms involved were relatively small with mean size of 0.59 ha. It was gathered from the respondents that the small farm size per farmer was due to the difficulty in getting land through inheritance, leasing and even purchasing. This average farm size indicated small scale nature of yam farming business in the area. The mean household size was 7.21 people. This large household size could be useful where there is dependency on family labour but could again constitute a threat to commercialization of agriculture because of increased household consumption.

Moreover in Table 1, the average year of formal education was 13.44 years. At times, the level of formal education is one of the determinants of farmer's awareness and interest in the use of new innovations and technologies.

Also, the farmers have substantial years of experience in yam production. The average farming experience was 14.37 years while the mean age of the respondents was 40.3 years, meaning that the farmers were relatively young and agile. The average distance between the yam growers houses and their farms was $1.54 \mathrm{~km}$ while, about $64 \%$ of them had access to credit facilities.

Production function analysis: The estimates of the Stochastic Frontier Production Function (SFPF) for yam farms are shown in Table 2. As shown in Table 2, the estimated sigma square $\left(\delta^{2}\right)$ of 0.037 was significantly different from zero at $5 \%$ level of significance. This 
Agric. J., 6 (2): 40-46, 2011

Table 1: Summary statistics for variables in the stochastic frontier model for yam farmers in Nigeria

\begin{tabular}{|c|c|c|c|c|}
\hline Variables & Minimum & Maximum & Mean & Standard deviation \\
\hline Output ( & $80,102.81$ & $254,561.21$ & $97,004.72$ & $119,561.12$ \\
\hline Yam sett cost ( & $48,030.84$ & $76,368.36$ & 29101.42 & $35,868.34$ \\
\hline Labour (mandays) & 93.48 & 339.50 & 224.30 & 234.41 \\
\hline Herbicides and pesticide cost ( & $2,440.64$ & $25,006.39$ & $17,403.66$ & $10,512.34$ \\
\hline Farm size $(\mathrm{Ha})$ & 0.10 & 3.94 & 0.59 & 0.47 \\
\hline Fertilizer cost $(\AA)$ & $1,300.61$ & $15,000.50$ & $10,994.44$ & 8806.23 \\
\hline Farm tools cost $(\mathbb{N})$ & $1,421.52$ & $5,461.85$ & $2,461.71$ & $2,315.05$ \\
\hline Household size & 3.00 & 9.00 & 7.21 & 6.40 \\
\hline Years of formal education (year) & 5.00 & 18.00 & 13.44 & 10.02 \\
\hline Farming experience (year) & 3.00 & 30.00 & 14.37 & 19.51 \\
\hline Age (y ear) & 25.00 & 64.00 & 40.30 & 50.04 \\
\hline Farm distance $(\mathrm{km})$ & 0.53 & 2.00 & 1.54 & 0.98 \\
\hline Access to credit & 0.00 & 1.00 & 0.64 & 0.51 \\
\hline
\end{tabular}

Table 2: Modified OLS and maximum-likelihood estimates of stochastic cobb-douglas production frontier for Nigerian yam producers

\begin{tabular}{|c|c|c|c|}
\hline Functions & Parameters & Model 1 & Model 2 \\
\hline \multicolumn{4}{|l|}{ Production function } \\
\hline Constant & $\beta_{0}$ & $-2.34^{*}(0.865)$ & $-4.675^{*}(0.645)$ \\
\hline Yam sett used ( & $\beta_{1}$ & $0.114^{* *}(0.058)$ & $-0.437^{*}(0.162)$ \\
\hline Labour used (manday) & $B_{2}$ & $-0.540(0.447)$ & $-0.008^{*}(0.003)$ \\
\hline Herbicides and pesticide used ( & $\beta_{3}$ & $0.305(0.254)$ & $0.017(0.011)$ \\
\hline Farm size (Ha) & $\beta_{4}$ & $0.175^{* * *}(0.088)$ & $1.098^{* *}(0.559)$ \\
\hline Fertilizer used (A) & $B_{5}$ & $0.513(0.395)$ & $0.423(0.325)$ \\
\hline Farm tools used ( & $\beta_{6}$ & $0.204(0.166)$ & $0.026^{* *}(0.013)$ \\
\hline \multicolumn{4}{|l|}{ Inefficiency model } \\
\hline Constant & $\delta_{0}$ & 0 & $2.523 *(0.708)$ \\
\hline Household size & $\delta_{1}$ & 0 & $0.023(0.016)$ \\
\hline Year of formal education (year) & $\delta_{2}$ & 0 & $-0.368 * *(0.147)$ \\
\hline Farming experience (year) & $\delta_{3}$ & 0 & $-0.294^{* * *}(0.127)$ \\
\hline Farmers age (year) & $\delta_{4}$ & 0 & $-0.365(0.272)$ \\
\hline Distance between farmer's house and the farm (km) & $\delta_{5}$ & 0 & $0.187(0.150)$ \\
\hline Access to credit yes $=1$, no $=0$ & $\delta_{6}$ & 0 & $-0.243^{* * *}(0.122)$ \\
\hline \multicolumn{4}{|l|}{ Variance parameter } \\
\hline Sigma square & $\delta^{2}$ & 0.395 & $0.037^{* *}(0.017)$ \\
\hline Gamma & $\gamma$ & 0 & $0.882^{* * *}(0.347)$ \\
\hline Log likelihood function & $\mathrm{L}(\mathrm{H})$ & 30.451 & 44.892 \\
\hline
\end{tabular}

Figures in parentheses are standard error. "Estimate is significant at $1 \%$ level and ${ }^{* *}$ estimate is significant at $5 \%$ level of significance

indicates a good fit of the model and the correctness of the specified distributed assumption of the composite error term. The study showed that there was presence of technical inefficiency among the farmers as confirmed by a test of hypothesis for the presence of inefficiency effects using the generalized likelihood ratio test and significance of the estimated gamma $(\gamma)$ shown in Table 2. Using Eq. 5, the Chi-square $\left(\chi^{2}\right)$ distribution shows that the computed Chi-square is 28.672 while the critical value of the chi-square at $5 \%$ with $6^{\circ}$ of freedom is 12.59 . Since, $\chi^{2}$ calculated is $>\chi^{2}$ tabulated, the null hypothesis of no inefficiency effects $(\gamma=0)$ in yam production was rejected and hence model 2 was chosen as the lead model. Confirming the inefficiency effects further is the gamma value of 0.882 for model 2 which was significant at $5 \%$ level of significance.

This implies that about $88 \%$ variation in the value of yam output was due mainly to differences in their technical efficiencies or technical inefficiencies while the remaining $12 \%$ can be attributed to random errors. According to Table 2, the estimated coefficient of cost of yam sett used and labour used were significant at 1\% while those of farm size and cost of farm tools used were significant at 5\% level of significance. This shows that these four inputs were significantly different from 0 and of importance in production of yam in the study area.

Determinants of technical inefficiency of yam farmers: In order to improve the efficiency of production, there is need to examine the factors that cause inefficiency. Explanations are provided for the relative efficiency levels among farmers through the estimated coefficient of the inefficiency model.

Table 2 shows that the year of formal education, farming experience and access to credit are the main socio-economic characteristics that affect the technical inefficiency of yam farmers significantly at 5\% level of significance. This is in consonance with apriori expectations. Other variables such as household size, farmer's age and distance between farmer's house and the farm are not significantly different from 0 at the $5 \%$ level of significance. The estimated coefficient for household 
Agric. J., 6 (2): 40-46, 2011

Table 3: Deciles range distribution of yam producers technical efficiency

\begin{tabular}{lcc}
\hline Efficiency class index & Frequency & Percent \\
\hline $0.41-0.50$ & 23 & 9.58 \\
$0.51-0.60$ & 47 & 19.58 \\
$0.61-0.70$ & 64 & 26.67 \\
$0.71-0.80$ & 39 & 16.25 \\
$0.81-0.90$ & 37 & 15.42 \\
$0.91-1.00$ & 30 & 12.50 \\
Total & 240 & 100.00 \\
\hline
\end{tabular}

Mean $\mathrm{TE}=0.698$, Minimum $\mathrm{TE}=0.343$, Maximum $\mathrm{TE}=0.962$

size is positively related to technical inefficiency. This implies that as the number of household members increases, technical inefficiency increases and this leads to reduction in technical efficiency. This is in conformity with the findings of Muhammad-Lawal et al. (2009). This may happen when most of the farming household members are very young and their effects in terms of labour provision have not been felt in yam production. On the other hand, a negative correlation exists between the year of formal education and technical inefficiency, implying that any increase in the value of this variable results in a rise in production efficiency. This also shows that the farmers level of technical inefficiency declines with more formal education.

This result is in conformity with the assumption that higher educational level leads to higher rate of improved technology and techniques of production adoption. This, in return will reduce the level of technical inefficiency in production. Moreover, farming experience is negatively related to technical inefficiency. This implies that the farmers with more experience tend to be more efficient in production because more skills are developed. The result corroborates the findings of Ram (1980) that with increased years of experience, farmers become more specialized.

In addition, the age of the farmers has a negative influence on technical inefficiency. This shows that old farmers are more technically efficient in production of yam. This may happen when the older farmers are more experienced and have interest in the use of new methods of production.

The positive coefficient for distance between farmers house and the farm implies that the more the distance the less the efficiency. Long distance leads to inefficiency especially in a situation where the farmer treks to farm everyday. Finally, access to credit has a negative and significant effect on technical inefficiency. Financial difficulties of the farmers are reduced especially at the beginning of the planting season, thus enhancing their efficiencies.

Yam producers technical efficiency indexes: Table 3 shows the distribution of yam farmers according to their technical efficiency in production. The frequency
Table 4: Elasticities of production among yam producers

\begin{tabular}{lc}
\hline Variables & Elasticity of production \\
\hline Yam sett used & -0.437 \\
Labour used & -0.008 \\
Herbicides and pesticide used & 0.017 \\
Farm size & 1.098 \\
Fertilizer used & 0.423 \\
Farm tools used & 0.026 \\
Return to scale & 1.119 \\
\hline
\end{tabular}

distribution of efficiency indexes shows high technical efficiency variations among the respondents. From Table 3 , it can be observed that majority of the farmers (about $72.08 \%$ ) have technical efficiency indexes between 0.41 and 0.80 .

The Technical Efficiencies (TE) of the yam farms ranged between 0.343 and 0.962 with a mean of 0.698 . According to Grabowseki et al. (1990), a farm is considered technically inefficient even if the farm has a technical efficiency index of $82 \%$. If this standard is used, the number of yam producers in the study area considered to be technically efficient is about $27.92 \%$.

The mean value (0.698) indicates that if the efficiency of input usage is increased by $0.302(1-0.698)$, the farmers will be operating on the production frontier. This shows that on the average, farmers were able to obtain about $70 \%$ of potential output from a given mix of inputs used in production. These findings reveal the presence of technical inefficiencies whose elimination could lead to the improvement of the technical efficiency of yam producers.

Elasticities of production and Returns To Scale (RTS): The estimated elasticities of production and return to scale for the yam farms are shown in Table 4 . The partial elasticity values estimated show the relative importance of every factor used in yam production.

It revealed farm size to be the most important factor in yam production. The partial elasticities of production for all the variables showed a positive return with exception of yam sett cost used and labour used which were inversely related to value of yam output.

The return to scale was positive and greater than unity. This shows that yam production was in stage 1 of the production surface. The value 1.119 indicates an increasing return to scale. This is an indication that yam producers could benefit from the economies of scale linked to increasing returns in order to enhance production. At this stage of irrational production (stage 1), production could be increased by using more of the resources with positive elasticity. These findings are in conformity with previous study by Ojo and Afolabi (2003). 


\section{CONCLUSION}

This study examined the technical performance and its determinants in yam production among farmers in Nigeria. To achieve these objectives, maximum likelihood method was used to estimate the stochastic frontier production function. The analysis showed that the sum of the partial output elasticities with respect to all resources used in production was 1.119. This revealed an increasing return to scale in yam production. The implication is that a proportional increase in those variables with positive coefficient leads to a more than proportional increase in the value of yam output. This shows that farmers could benefit from economies of scale linked to increasing returns to boost yam production.

In addition, the results revealed that there was presence of technical inefficiency among the farmers as confirmed by a test of hypothesis and significance of the estimated gamma $(\gamma)$ coefficient. About $88 \%$ variation in the value of yam output was due to differences in their technical efficiencies or inefficiencies. Out of the 6 variables, 4 inputs were significantly different from zero and of importance in production of yam in the study area. Moreover, analysis of technical inefficiency model indicated that year of formal education, farming experience and access to credit were the main socioeconomic characteristics having a significant and negative effect on the yam producers technical inefficiency. It was also observed that about $72 \%$ of the farmers had technical efficiency indexes between 0.41 and 0.80 . The technical efficiencies ranged between 0.343 and 0.962 with a mean of 0.698 .

\section{RECOMMENDATIONS}

In order to improve the technical efficiency among yam farmers and boost food security in Nigeria, the following recommendations are suggested:

- The farmers should be encouraged to produce more by making available and affordable an improved and disease free variety of yam sett. This is important in order to remove the limitation placed upon the cultivation of yam due to high cost of planting material
- Moreover for an effective utilization of available labour in production of yam, there should be an improvement in wage rate and incentive to farm researchets. Also, since farm size had a positive effect on yam output value, more fertile land should be reserved by policy for its cultivation

- Finally, the variables, year of formal education, farming experience and access to credit should be manipulated by policy makers in order to improve the technical efficiency of yam producers in Nigeria

\section{REFERENCES}

Akinwunmi, J.A., 1999. Mobilizing Small-Scale Savings through Co-operative Saving and Credit Associations. In: Mobilizing Savings Among NonTraditional Users of the Banking Industry in Nigeria, Akinyosoye, V.O (Ed.). Ibadan University Press, Ibadan, pp: 6-11.

Babaleye, T., 2005. Improving Livelihood Yam Production System. The International fund for Agricultural Development, London.

Battese, G.E. and T.J. Coelli, 1995. A model for technical inefficiency effect in a stochastic frontier production function for panel data. Empirical Econ., 20: 325-332.

Grabowseki, R., S. kraft, C. Pasurka and H.y. Aly, 1990. A ray-homothetic production frontier and efficiency, grain farms in Southern Illinois. Eur. Rev. Agric. Econ., 17: 435-448.

Greene, W.H., 1980. Maximum likelihood estimation of econometric frontier functions. J. Economet, 13: $27-56$.

Jondrow, J., C.A.K. Lovell, I.S. Materov and P. Schmidt, 1982. On the estimation of technical inefficiency in the stochastic frontier production function model. J. Econ., 213: 233-238.

Muhammad-Lawal, A., O.A. Omotesho and A. Falola, 2009. Technical efficiency of youth participation in agriculture: A case study of the youth in agriculture programme in Ondo State, South Western Nigeria. Nig. J. Agric. Food Eviron., 5: 20-26.

Ojo, S.O. and J.A. Afolabi, 2003. Effects of farm distance on productivity of farms in Nigeria. J. Applied Sci., 6: 3331-3341.

Ram, R., 1980. Role of education in production: A slightly new approach. Quarterly J. Econ., 95: 365-375. 